\title{
DEFRAGMENTING STRUKTUR BERPIKIR MELALUI REFLEKSI UNTUK MEMPERBAIKI KESALAHAN SISWA MENYELESAIKAN SOAL CERITA
}

\author{
Achmad Muhtadin \\ Program Studi Pendidikan Matematika, Universitas Mulawarman \\ Email: achmad.muhtadin@fkip.unmul.ac.id
}

\begin{abstract}
ABSTRAK
Sebagian siswa masih kesulitan dalam menyelesaikan soal cerita. Penelitian ini bertujuan untuk mengetahui dan mendeskripsikan defragmenting struktur berpikir melalui refleksi untuk memperbaiki kesalahan siswa dalam menyelesaikan soal cerita materi balok di kelas IX SMPN 34 Samarinda. Defragmenting struktur berpikir siswa dilakukan melalui refleksi dari hasil wawancara peneliti dengan subyek. Siswa diberikan soal cerita kemudian diambil 3 orang yang dijadikan sebagai subjek penelitian dengan metode think-out-loud (TOL). Dari hasil penelitian ditemukan bahwa kesalahan siswa adalah proses memahami soal, dalam melakukan operasi perkalian dan pembagian, siswa kurang terbiasa dengan jenis soal terbuka, dan ketidaklengkapan struktur berpikir siswa dalam penyelesaian. Adapun defragmenting yang dilakukan peneliti untuk memperbaiki kesalahan siswa tersebut adalah, meminta S1 untuk menuliskan bagian yang diketahui dan yang ditanyakan dari soal yang diberikan dan memberikan indeks berbeda untuk membedakan keterangan pada kolam lama dan baru, meminta S1 untuk mengingat kembali tentang cara menghitung volume, kemudian menentukan volume kolam awal $V_{1}=p_{1} \times l_{1} \times t_{1}$ dan volume kolam baru $V_{2}=4 \times V_{1}$, mensubtitusikan hasil $V_{2}$ dan $l_{2}$ ke rumus volume kolam baru $V_{2}=p_{2} \times l_{2} \times t_{2}$, menyelesaikan $p_{2} \times t_{2}=16$ dengan bantuan tabel, mengecek kembali jawaban yang diperoleh dengan mengambil pasangan bilangan pada tabel kemudian mencocokkan hasil $V_{2}=p_{2} \times l_{2} \times t_{2}$ dengan $V_{2}=4 \times V_{1}$.
\end{abstract}

Kata kunci: Defragmenting, Kesalahan Siswa, Soal Cerita.

\begin{abstract}
A part of students still have difficulity in solving word problems. The purpose of this study is to obtain a description of defragmenting thinking structure through reflection to correct students' mistakes in solving word problems of cuboid materials at $9^{\text {th }}$ grades of SMPN 34 Samarinda. Defragmenting thinking structure of students were taken with reflection from the interview result researcher to subjects. They were given the word problems of cuboid materials, then three of them were taken as the subjects of this study using think-out-loud (TOL) method. The study result, it was found that the students' mistakes in solving word problems of cuboid materials were among other understanding word problems, in computing, not accostumed to open ended word problems, and the uncompleteness of their thinking structure in process of solving the


word problems. The defragmenting that was done by the researcher to correct students' mistakes were: write the known parts, and the asked parts from the word problems given, and give different index to differentiate the notes in the old and new column; memorize about the way how to count the volume, then to decide the volume of the first pool $V_{1}=p_{1} \times l_{1} \times t_{1}$ and the volume of the new pool $V_{2}=4 \times V_{1}$, substitute the result of $V_{2}$ and $l_{2}$ to the formula of the new pool $V_{2}=p_{2} \times l_{2} \times t_{2}$; accomplish $p_{2} \times t_{2}=16$ with the help of table; recheck their conclusion by taking paired number in the table then match the result of $V_{2}=p_{2} \times l_{2} \times t_{2}$ with $V_{2}=4 \times V_{1}$.

Keywords: Defragmenting, Students Mistakes, Word Problems.

\section{PENDAHULUAN}

Matematika merupakan salah satu ilmu dasar yang sangat penting dalam dunia pendidikan. Matematika juga berperan menunjang perkembangan dan kemajuan ilmu-ilmu lain seperti: ilmu kimia, fisika dan komputer. Menurut Abdurrahman (2003), matematika adalah bahasa simbolis yang fungsi praktisnya adalah untuk mengekspresikan hubunganhubungan kuantitatif dan keruangan, sedangkan fungsi teoritisnya adalah untuk memudahkan berpikir. Pemahaman terhadap matematika dari kemampuan yang bersifat apresiatif akan berhasil mengembangkan kemampuan science dan teknologi yang semakin tinggi (Buchori, 2001).

Usaha yang dilakukan oleh guru di kelas untuk mengatasi kesulitan siswa dalam menyelesaikan soal cerita untuk mata pelajaran matematika, selain dengan memberi porsi soal cerita yang lebih banyak, juga mencoba menggunakan metode pembelajaran yang berbeda. Namun demikian masih banyak siswa yang mengalami kesulitan dalam menyelesaikan soal cerita. Budiyono (2008) menyatakan bahwa soal cerita masih merupakan soal yang cukup sulit bagi sebagian siswa. Kesalahan-kesalahan dilakukan siswa dalam menyelesaikan soal cerita yaitu kesalahan memahami soal, kesalahan mela-kukan komputasi dan kesalahan menginter-pretasikan jawaban model matematika (Rahardjo dan Astuti, 2011).

Berdasarkan hasil interview seorang guru bidang studi Matematika kelas VIII SMP Negeri 34 Samarinda yang dilakukan pada Maret 2019 menunjukkan bahwa kesulitan-kesulitan yang dihadapi siswa dalam menyelesaikan soal cerita, antara lain: (1) memahami soal, (2) membuat rencana, (3) pengetahuan prasyarat, (4) belum mampu memberikan alasan dan (5) penghitungan.

Geometri ruang sebagai salah satu materi yang diajarkan pada jenjang SMP, walaupun telah diajarkan sejak SD namun ternyata kemampuan siswa dalam menyelesaikan soal-soal dimensi tiga masih rendah. Sebagai contoh, siswa kesulitan dalam menyelesaikan soal bangun ruang dalam bentuk soal cerita. Hasil survey Programme for International Student Assessment (PISA) 2015 (dalam Suwaji, 2016) menunjukkan bahwa siswa lemah dalam geometri, khususnya dalam pemahaman ruang dan bentuk. Sedangkan menurut Gal \& Linchevski (Subanji, 2013) bahwa kesulitan siswa dalam 
merepresentasikan geometri mencakup: (1) organisasi perseptual (prinsip Gestalt), (2) pengenalan (proses bottom-up dan top-down); dan (3) representasi pengetahuan berbasis persepsi (representasi verbal versus gambar, gambaran mental dan hierarki)

Dalam penelitian ini, penataan (defragmenting) struktur berpikir siswa dilakukan melalui refleksi dari hasil wawancara peneliti dengan subyek. Refleksi ditujukan untuk melihat kembali secara keseluruhan proses penyelesaian soal cerita oleh siswa secara utuh. Refleksi menurut Suharsimi (2006) yaitu kegiatan untuk mengemukakan kembali apa yang sudah terjadi. Sedangkan menurut Kemmis dan Taggart (1998) refleksi meliputi kegiatan: analisis, sintesis, penafsiran (penginterpretasian), menjelaskan dan menyimpulkan. Melalui refleksi inilah peneliti melakukan penataan (defragmenting) untuk memperbaiki kesalahan-kesalahan yang muncul pada struktur berpikir siswa ketika menyelesaikan soal cerita pada materi balok.

\section{METODE PENELITIAN}

Jenis penelitian ini adalah penelitian kualitatif deskriptif ekploratif, karena data yang dikumpulkan pada umumnya berupa data verbal. Dalam penelitian ini peneliti ingin mengungkap bagaimana penataan (defragmenting) struktur berpikir melalui refleksi untuk memperbaiki kesalahan siswa dalam menyelesaikan soal cerita pada materi balok.

Siswa diberikan soal cerita kemudian diambil 3 orang yang dijadikan sebagai subjek penelitian dengan metode think-out-loud (TOL). Dalam metode TOL, siswa diminta untuk mengung- kapkan dengan keras apa yang sedang dipikirkan ketika mengerjakan masalah yang diberikan. Data yang diperoleh kemudian dikodekan dan dijadikan dasar untuk menggambarkan proses defragmenting yang dilakukan.

\section{HASIL PENELITIAN DAN PEMBA- HASAN}

\section{A. Hasil Penelitian}

Penelitian ini mendeskripsikan struktur berpikir dan proses defragmenting yang dilakukan oleh peneliti untuk memperbaiki kesalahan siswa dalam menyelesaikan soal cerita pada materi balok. Untuk itu dipaparkan tiga subjek penelitian yang memiliki karakteristik yang berbeda, yaitu subjek 1 (S1) merupakan siswa yang berkemampuan rendah, subjek 2 (S2) merupakan siswa yang berkemampuan sedang, dan subjek 3 (S3) merupakan siswa yang berkemampuan tinggi. Ketiga subjek penelitian ini digunakan untuk mengeksplorasi terjadinya struktur berpikir siswa dalam menyelesaikan soal cerita materi balok dan defragmenting yang dilakukan.

Struktur berpikir siswa dipaparkan untuk masing-masing soal cerita yang diberikan pada lembar tugas, yaitu soal cerita nomor 1 dan nomor 2. Deskripsi struktur berpikir masing-masing siswa disajikan baik sebelum kegiatan wawancara maupun selama wawancara pada saat refleksi. Selanjutnya juga digambarkan struktur berpikir siswa dalam menyelesaikan soal cerita baik sebelum defragmenting maupun setelah defragmenting dilakukan kemudian dibandingkan dengan struktur masalah yang diberikan.

Defragmenting Struktur Berpikir Melalui Refleksi Untuk Memperbaiki Kesalahan Siswa Achmad Muhtadin 
1. Defragmenting Struktur Berpikir S1 dalam Menyelesaikan Soal Cerita Nomor 1

a. Deskripsi struktur berpikir S1 dalam menyelesaikan soal cerita materi balok soal nomor 1 sebelum defragmenting.

Dalam menyelesaikan soal cerita materi balok nomor 1, sebagian struktur masalah sudah dikenal oleh S1. S1 mampu menyebutkan bahwa materi pada soal nomor 1 adalah materi bangun ruang sisi datar yaitu balok. Kemudian S1 sebenarnya secara tidak langsung sudah menuliskan pemisalan ukurannya, disini terlihat bahwa $\mathrm{S} 1$ sudah menggunakan huruf $p_{l}, l$, dan $t$. Hanya saja S1 tidak konsisten dalam menuliskan pemisalan.

Dalam menuliskan pemisalan ukurannya, S1 menggunakan keterangan ke-1 yang menandakan keterangan untuk kolam awal. Juga pada bagian yang diketahui, S1 tidak menuliskan secara lengkap kete-rangan-keterangan lain yang bisa di tulis pada bagian yang diketahui tersebut. Namun S1 bisa menyebutkannya pada saat wawancara dengan peneliti.

Berdasarkan jawaban yang ditulis S1 dan wawancara, berarti S1 sudah memahami bagian yang diketahui dari soal yang diberikan. Meskipun baru menuliskan $p_{l}, \quad l$, dan $t$, sedangkan berikutnya belum ditulis karena masih fokus untuk menghitung volume kolam ke-1. Hal ini berarti juga bahwa pemisalan ukurannya sebenarnya sudah ada di dalam pikiran S1. S1 tidak menuliskan bagian yang ditanyakan dalam lembar jawabannya tetapi S1 sudah memahami bagian yang ditanyakan dari masalah yang diberikan. Hal ini diungkapkan oleh S1 setelah peneliti melakukan wawancara dengannya.

Setelah menuliskan beberapa pemisalan pada bagian yang diketahui, S1 memulai menyelesaikan soal dengan menghitung volume 1 kolam ikan (lama) $=\mathrm{p} \times 1 \times \mathrm{t}$ dan diperoleh hasil perkalian $9 \times 3 \times 2=54 \mathrm{~m}^{3}$. Pada bagian yang diketahui S1 menuliskan pemisalan panjang ke-1 dengan $p_{1}$, namun pada saat menghitung volume ke-1 penulisan $p_{1}$ ditulis hanya $p$. Disini terlihat S1 masih ragu dan tidak konsisten dalam pemisalannya. Kemudian S1 me-nuliskan keterangan tanah yang bersisa dibuat dengan lebar $=6 \mathrm{~m}$ diberi keterangan sebagai lebar ke-2. Dalam hal ini S1 sudah memahami langkah awal menyelesaikan soal dengan menghitung volume kolam awal yang diperoleh dari mengalikan ukuran panjang, ukuran lebar dan dalam kolam awal. Ini berarti S1 sudah memahami materi yang terdapat pada soal adalah mengenai volume balok.

b. Deskripsi struktur berpikir S1 dalam menyelesaikan soal cerita materi balok nomor 1 saat defragmenting

Ketika peneliti menanyakan kembali pada S1, "Apakah sudah yakin dengan jawaban yang diperoleh?" S1 terdiam sejenak kemudian menjawab "tidak pak". S1 mengatakan bahwa tidak yakin dengan jawaban yang diperoleh dan masih bingung dalam mencari ukuran panjang dan tinggi kolam baru. S1 terlihat ragu dengan jawaban yang sudah ditemukannya ini. Selanjutnya peneliti mengajak S1 untuk melakukan refleksi atau mencoba memperbaiki kesalahan yang telah dilakukan S1 dengan membuat 
peta kognitif. Melalui alur berpikir yang dibuat S1, peneliti melakukan defragmenting yang bertujuan untuk mengingat kembali semua materi atau konsep-konsep yang berhubungan dengan masalah yang diberikan dan meminta S1 untuk menjelaskan setiap materi atau konsep yang saling terhubung.

\section{Efektivitas \\ Defragmenting \\ Struktur Berpikir S1 Dalam Menyelesaikan Soal Cerita Materi \\ Balok Nomor 2}

Soal cerita materi balok nomor 2 ini diberikan untuk meyakinkan bahwa defragmenting yang dilakukan melalui refleksi dalam memperbaiki kesalahan siswa efektif. Keefektifan defragmenting ditunjukkan oleh struktur berpikir S1 ketika menyelesaikan soal cerita materi balok nomor 2. S1 mampu memahami soal secara lengkap dan membuat perencanaan dengan baik sehingga memperoleh jawaban yang benar.

Pertama, S1 tanpa ragu lagi menuliskan pemisalan pada bagian yang diketahui dan yang ditanyakan secara lengkap dengan memberikan penambahan indeks I yang menunjukkan keterangan untuk kolam awal dan indeks II menunjukkan pemisalan untuk kolam baru.

Jawaban S1 sudah sesuai dengan struktur masalah yang dibuat oleh peneliti sehingga dapat dikatakan bahwa jawaban dari S1 adalah benar. Hal ini menunjukkan bahwa melalui refleksi dan alur berpikir yang dibuat oleh S1 pada pengerjaan soal cerita nomor 1 dan defragmenting yang dilakukan oleh peneliti dapat memberikan dampak yang positif bagi S1, yang ditunjukkan oleh hasil pekerjaannya dalam menyelesaikan soal cerita materi balok nomor 2. Defragmenting melalui refleksi dapat memperbaiki struktur berpikir S1 juga dapat menstrukturisasi struktur berpikir S1 menjadi struktur berpikir yang benar.

\section{Defragmenting Struktur Berpikir} S2 Menyelesaikan Soal Cerita Nomor 1

\section{a. Deskripsi struktur berpikir S2 dalam menyelesaikan soal cerita materi balok nomor 1 sebelum de- fragmenting}

Dalam menyelesaikan soal cerita materi balok nomor 1, sebagian struktur masalah sudah dikenal oleh S2. Walau S2 tidak menuliskan bagian yang diketahui dan yang ditanyakan pada lembar jawaban, namun S2 bisa menyebutkan bagian yang diketahui dan bagian yang ditanyakan dari soal. S2 juga sudah menuliskan pemisalan ukurannya secara tidak langsung, disini terlihat bahwa S2 sudah menggunakan huruf $p, l$, dan $t$ dalam pengerjaannya. S2 tidak menuliskan bagian yang ditanyakan dari soal pada lembar jawabannya. Namun S2 mampu menjelaskan kepada peneliti bagian yang ditanyakan dari soal.

Ketika pertama kali menghadapi soal, S2 sudah bisa memahami soal cerita yang diberikan, yaitu yang diketahui adalah ukuran panjang, ukuran lebar, dan tinggi kolam lama. Kemudian volume kolam baru sama dengan 4 kali volume kolam lama dan ukuran lebar kolam baru $6 \mathrm{~m}$. S2 juga sudah mengetahui apa yang ditanyakan dari soal, yaitu ukuran panjang dan tinggi kolam baru. Untuk menyelesaikan soal cerita yang diberikan 
ini, S2 mulai menyelesaikan soal dengan menuliskan kolam awal $=p \times l \times t$, padahal yang dimaksud S2 sebenarnya adalah volume kolam awal.

\section{b. Deskripsi struktur berpikir S2 dalam menyelesaikan soal cerita materi balok nomor 1 saat $d e$ - fragmenting}

S2 mengawali alur berpikir yang dibuat dengan menuliskan materi balok sebagai masalah utama. Kemudian S2 membuat yang diketahui dari masalah yang diberikan, setelah itu membuat yang ditanyakan. Sebelumnya S2 menuliskan pemisalan $p, l$ dan $t$ untuk kolam lama dan untuk kolam baru sama. Sehingga pada lembar pengerjaan S2 tulis sebanyak dua kali tanpa ada keterangan yang dituliskan merupakan $p, l$ dan $t$ untuk kolam lama atau kolam baru.

Oleh karena itu, peneliti melakukan defragmenting 1. Setelah defragmenting 1, S2 menentukan volume kolam baru, terlebih dahulu mencari volume kolam lama. Dalam menuliskan volume kolam lama, S2 hanya menuliskan kolam lama dan dalam menuliskan rumus volume kolam lama dengan menuliskan rumus volume kolam baru. S2 menuliskan rumus yang sama tanpa ada pemisalan beda menuliskan $p, l$ dan $t$, yaitu $p \times l \times t$ sehingga peneliti melakukan defragmenting 2. S2 akhirnya mempunyai ide untuk menentukan ukuran panjang dan tinggi kolam baru, namun demikian proses yang digunakan S2 salah, yaitu dengan coba-coba (trial and error). Jadi dilakukan defragmenting 3. Kemudian defragmenting 4 dilakukan peneliti karena S2 tidak bisa menuliskan kemungkinan lain dari ukuran panjang dan tinggi kolam. S2 melakukan pengecekan kembali jawaban yang diperoleh setelah peneliti melakukan defragmenting 5 .

\section{Efektivitas Defragmenting Struktur} Berpikir S2 Dalam Menyelesaikan Soal Cerita Materi Balok Nomor 2

Soal cerita materi balok nomor 2 ini diberikan untuk meyakinkan bahwa defrag-menting yang dilakukan melalui refleksi dalam memperbaiki kesalahan siswa efektif. Keefektifan defragmenting ditun-jukkan oleh struktur berpikir S2 ketika menyelesaikan soal cerita materi balok nomor 2 ini. S2 mampu memahami masalah secara lengkap dan membuat perencanaan dengan baik sehingga memperoleh jawaban yang benar.

Jawaban S2 sudah sesuai dengan struktur masalah yang dibuat oleh peneliti sehingga dapat dikatakan bahwa jawaban dari S2 adalah benar. Hal ini menunjukkan bahwa melalui refleksi dan dengan alur berpikir yang dibuat oleh S2 pada pengerjaan soal cerita nomor 1 dan defragmenting yang dilakukan oleh peneliti dapat memberikan dampak yang positif bagi S2, yang ditunjukkan oleh hasil pekerjaannya dalam menyelesaikan soal cerita materi balok nomor 2 . Defragmenting melalui refleksi dapat memperbaiki struktur berpikir S2 (siswa) juga dapat menstrukturisasi struktur berpikir S2 (siswa) menjadi struktur berpikir yang benar.

5. Defragmenting Struktur Berpikir S3 Dalam Menyelesaikan Soal Cerita Nomor 1

a. Deskripsi struktur berpikir S3 dalam menyelesaikan soal cerita materi balok nomor 1 sebelum defragmenting 
Dalam menyelesaikan soal cerita materi balok nomor 1, sebagian struktur masalah sudah dikenal oleh S3. Meskipun S3 tidak menuliskan bagian yang diketahui dan yang ditanyakan pada lembar jawaban, namun S3 bisa menyebutkan bagian yang diketahui dari soal. S3 juga sudah menuliskan pemisalan ukurannya secara tidak langsung dan S3 sudah menggunakan huruf $p, l$, dan $t$ dalam pengerjaannya.

Dalam proses penyelesaiannya S3 mengalami kebingungan dan melakukan kesalahan dalam menentukan cara mencari ukuran panjang dan tinggi kolam baru sehingga S3 mencari jawabannya melalui prosedur yang salah. Namun demikian, tidak berarti S3 tidak mampu menyelesaikan masalah tersebut. Mungkin saja S3 belum mengoptimalkan struktur berpikirnya karena konsepkonsep yang tersimpan di dalam memori S3 mengalami defragmentasi atau tidak terhubung dengan baik. Oleh karena itu, S3 tidak melakukan refleksi lagi.

\section{b. Deskripsi struktur berpikir S3 dalam menyelesaikan soal cerita materi balok nomor 1 saat $d e$ - fragmenting}

S3 mengawali alur berpikir yang dibuat dengan menuliskan materi balok sebagai masalah utama. S3 membuat yang diketahui dari masalah yang diberikan, setelah itu membuat yang ditanyakan. Sebelumnya S3 menuliskan pemisalan $p, l$ dan $t$ untuk kolam lama dan untuk kolam baru sama. Sehingga pada lembar pengerjaan S3 tulis sebanyak dua kali tanpa ada keterangan yang dituliskan merupakan $p, l$ dan $t$ untuk kolam lama atau kolam baru.
Oleh karena itu peneliti melakukan defragmenting 1. Setelah defragmenting 1, S3 menentukan volume kolam baru, terlebih dahulu mencari volume kolam lama. Dalam menuliskan rumus volume kolam lama, S3 menuliskan rumus yang sama dengan rumus volume kolam baru. S3 menuliskan rumus yang sama tanpa ada pemisalan yang berbeda dalam menuliskan $p, l$ dan $t$, yaitu $p \times l \times t$ sehingga peneliti melakukan defragmenting 2. S3 akhirnya mempunyai ide untuk menentukan ukuran panjang dan tinggi kolam baru, yaitu dengan menganggap bahwa ukuran panjang kolam baru sama dengan ukuran panjang kolam lama jadi dilakukan defragmenting 3. Kemudian defragmenting 4 dilakukan peneliti karena S3 tidak bisa menuliskan kemungkinan lain dari ukuran panjang dan tinggi kolam. S3 melakukan pengecekan kembali terhadap jawaban yang diperoleh setelah peneliti melakukan defragmenting 5 .

\section{Efektivitas Defragmenting Struktur Berpikir S3 Dalam Menyelesaikan Soal Cerita Materi Balok Nomor 2}

Soal cerita materi balok nomor 2 ini diberikan untuk meyakinkan bahwa defragmenting yang dilakukan melalui refleksi dalam memperbaiki kesalahan siswa efektif. Keefektifan defragmenting ditunjukkan oleh struktur berpikir S3 ketika menyelesaikan soal cerita materi balok nomor 2. S3 mampu memahami soal secara lengkap dan membuat perencanaan dengan baik sehingga memperoleh jawaban yang benar.

Jawaban S3 sudah sesuai dengan struktur masalah yang dibuat oleh peneliti sehingga dapat dikatakan bahwa jawaban 
dari S3 adalah benar. Hal ini menunjukkan bahwa melalui refleksi dan dengan alur berpikir yang dibuat oleh S3 pada pengerjaan soal cerita nomor 1 dan defragmenting yang dilakukan oleh peneliti dapat memberikan dampak yang positif bagi S3, yang ditunjukkan oleh hasil pekerjaannya dalam menyelesaikan soal cerita materi balok nomor 2 . Defragmenting melalui refleksi dapat memperbaiki struktur berpikir S3 juga dapat menstrukturisasi struktur berpikir S3 menjadi struktur berpikir yang benar

\section{B. Pembahasan}

Penelitian ini mendeskripsikan struktur berpikir siswa baik sebelum defragmenting maupun setelah defragmenting dalam menyelesaikan soal cerita materi balok. Defragmenting yang dilakukan mengacu pada beberapa ahli seperti Wahono (2009), Maag (2004), McKay dan Allen dan Woolfolk (dalam Selvera, 2013). Defragmenting dimaksudkan untuk mengkaji dan memperbaiki struktur berpikir siswa dalam menyelesaikan soal cerita materi balok yang diadopsi berdasarkan langkah pemecahan masalah menurut Polya (1973).

\section{Struktur Berpikir S1 Sebelum Dan Setelah Defragmenting}

Keefektifan defragmenting yang dilakukan oleh peneliti ditunjukkan oleh tertatanya struktur berpikir S1 dalam menyelesaikan soal cerita materi balok nomor 2. S1 mampu menyelesaikan soal cerita yang diberikan dengan baik dan menemukan jawaban yang benar sesuai dengan struktur masalah yang dibuat peneliti. Menurut Wahono (2009) setelah dilakukan defragmentasi, semua data akan saling terhubung dan tertata sehingga memudahkan untuk mengambil dan menjelaskan setiap data yang dipanggil.

Indikator efektifnya defragmenting yang dilakukan oleh peneliti dan tampak pada S1 adalah S1 mampu mengingat, menjelaskan, dan memahami materi atau konsep yang diperlukan untuk menyelesaikan soal cerita, S1 mampu membuat hubungan setiap konsep yang diperlukan yang terkait dengan soal cerita yang diberikan, dan ketiga S1 mampu memperbaiki kesalahan-kesalahan yang dibuat dan menemukan jawaban yang benar.

\section{Struktur Berpikir S2 Sebelum Dan Setelah Defragmenting}

Keefektifan defragmenting yang dilakukan oleh peneliti ditunjukkan oleh tertatanya struktur berpikir S2 dalam menyelesaikan soal cerita materi balok nomor 2. S2 mampu menyelesaikan soal cerita yang diberikan dengan baik dan menemukan jawaban yang benar sesuai dengan struktur masalah yang dibuat peneliti. Menurut Wahono (2009) setelah dilakukan defragmentasi, semua data yang terdefrag akan saling terhubung dan tertata sehingga memudahkan untuk mengambil dan menjelaskan setiap data yang dipanggil.

Indikator efektifnya defragmenting yang dilakukan oleh peneliti dan tampak pada S2 adalah S2 mampu mengingat, menjelaskan, dan memahami materi atau konsep yang diperlukan untuk menyelesaikan soal cerita, S2 mampu membuat hubungan setiap konsep yang diperlukan yang terkait dengan soal cerita yang diberikan, dan ketiga S2 mampu memperbaiki kesalahan-kesalahan yang dibuat dan menemukan jawaban yang benar. 


\section{Struktur S3 Berpikir Sebelum Dan Setelah Defragmenting}

Kefektifan defragmenting yang dilakukan oleh peneliti ditunjukkan oleh tertatanya struktur berpikir S3 dalam menyelesaikan soal cerita materi balok nomor 2. S3 mampu menyelesaikan soal cerita yang diberikan dengan baik dan menemukan jawaban yang benar sesuai dengan struktur masalah yang dibuat peneliti. Menurut Wahono (2009) setelah dilakukan defragmentasi, semua data yang terdefrag akan saling terhubung dan tertata sehingga memudahkan untuk mengambil dan menjelaskan setiap data yang dipanggil.

Indikator efektifnya defragmenting yang dilakukan oleh peneliti dan tampak pada S3 adalah S3 mampu mengingat, menjelaskan, dan memahami materi atau konsep yang diperlukan untuk menyelesaikan soal cerita, S3 mampu membuat hubungan setiap konsep yang diperlukan yang terkait dengan soal cerita yang diberikan, dan ketiga S3 mampu memperbaiki kesalahan-kesalahan yang dibuat dan menemukan jawaban yang benar.

\section{KESIMPULAN}

Berdasarkan hasil penelitian dan pembahasan, dapat disimpulkan bahwa bahwa kesalahan siswa adalah 1) proses memahami soal; 2) dalam melakukan operasi perkalian dan pembagian; 3) siswa kurang terbiasa dengan jenis soal terbuka; dan 4) ketidaklengkapan struktur berpikir siswa dalam penyelesaian soal.

Adapun defragmenting yang dilakukan peneliti untuk memperbaiki kesalahan siswa adalah memintanya untuk
1) menuliskan bagian yang diketahui dan ditanyakan lalu memberikan indeks berbeda untuk membedakan keterangan pada kolam lama dan baru; 2) mengingat kembali tentang cara menghitung volume, dan menentukan volume kolam awal $V_{1}=p_{1} \times l_{1} \times t_{1}$ dan volume kolam baru $V_{2}=4 \times V_{1}$; 3) mensubtitusikan hasil $V_{2}$ dan $l_{2}$ ke rumus volume kolam baru $\left.V_{2}=p_{2} \times l_{2} \times t_{2} ; 4\right)$ menyelesaikan $p_{2} \times t_{2}=16$ dengan bantuan table; 5) mengecek kembali jawaban yang diperoleh dengan mengambil pasangan bilangan pada tabel lalu mencocokkan hasil $V_{2}=p_{2} \times l_{2} \times t_{2}$ dengan $V_{2}=4 \times V_{1}$.

Efektivitas defragmenting yang dilakukan oleh peneliti dapat ditunjukkan bahwa siswa mampu untuk 1) mengingat, menjelaskan, dan memahami materi atau konsep yang diperlukan untuk menyelesaikan soal; dan 2) mampu memperbaiki kesalahan-kesalahan yang dibuat dan memberikan jawaban yang benar.

\section{DAFTAR PUSTAKA}

Abdurrahman, M. (2003). Pendidikan Bagi Anak Berkesulitan Belajar. Rineka Cipta.

Budiyono. (2008). Kesalahan

Mengerjakan Soal Cerita Dalam Pembelajaran Matematika.

Paedagogia. 11(1): 1-8.

Polya, G. (1973). How to Solve It (New Aspect of Mathematical Method). Princeton University Press.

Rahardjo, M dan Waluyati, A. (2011). Pembelajaran Soal Cerita Operasi Hitung Campuran di Sekolah Dasar 
| Jurnal PRIMATIKA, Volume 9, Nomor 1, Juni 2020

(Modul Matematika SD dan SMP Program Bermutu). PPPPTK Matematika.

Subanji. (2013). Revitalisasi Pembelajaran Bermakna dan Penerapannya dalam Pembelajaran Matematika Sekolah. Disampaikan pada Seminar Nasional TEQIP 2013, 9 November 2013. UM Press. 